\title{
Characteristics of Surface Layers Produced by Shot Peening
}

\author{
Volker Schulze
}

Institut für Werkstofłkunde I, Universität Karlsruhe (TH), Karlsruhe, Germany

\section{Introduction}

Production processes, especially mechanical surface treatments like shot peening, lead to changes in the materials state close to the surface, which severely affect the success of the treatment, especially the resulting fatigue properties. Formerly these effects on fatigue life were controversely discussed as effects of mechanical workhardening, which first were postulated to be dominating by Föppl and his group [1,2], and effects of compressive residual stresses, which first were assumed to increase the fatigue properties by Thum and his group $[3,4]$. Additionally, effects of topography on fatigue properties were studied by Houdremont and Mailänder [5] and Siebel and Gaier [6]. Today it is well known that most of the changes of surface characteristics induced by shot peening which are listed in Fig. 1 and the stability of these changes may affect the fatigue properties of components and that these effects can be described in the so called concept of local fatigue properties $[7,8,9]$. Therefore the influence of process parameters of the shot peening treatments listed in Fig. 2 on the surface characteristics has to be well known. Besides the parameters concerning the peening device or the shot, the parameters concerning the workpiece are of high interest. Especially the workpiece temperature and the prestress are altered in modifications of the peening process named warm peening and stress peening which will be discussed separately. In some cases additional annealing treatments are used to achieve further improvements of the material state close to the surface.

In the present paper a systematic overview of up to date knowledge about the changes in the surface state due to shot peening is given by discussing characteristic examples concerning changes of the topography, residual stress state, workhardening state and microstructure of components due to shot peening. A special focus will be drawn to the previously mentioned modifications of the conventional shot peening process like stress peening, warm peening and peening plus subsequent annealing, which show improvements in the surface properties or at least improvements of the stability of the induced surface state.

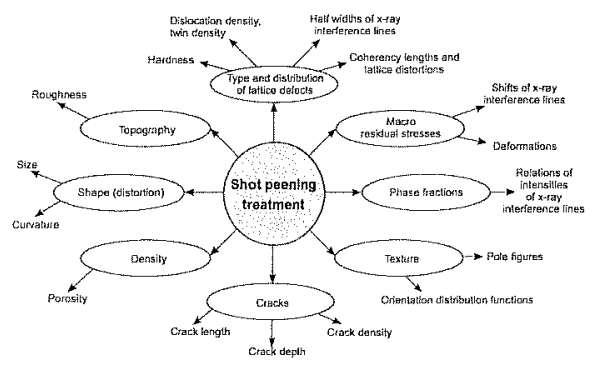

Figure 1: Properties of the workpiece influenced by shot peening and measures for them [acc.51]

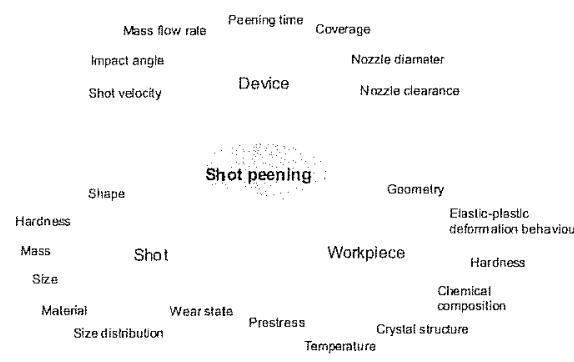

Figure 2: Parameters influencing the results of shot peening treatments 


\section{Surface Characteristics}

\section{$2.1 \quad$ Topography}

In [10], an overview of roughness values after different shot peening treatments of the steel AISI 4140 is given. Fig. 3 shows that increasing peening pressures lead to growing values of roughness. While they increase only slightly at the quenched state, these increases are the more pronounced the lower the workpiece hardness is. Increasing size and hardness of the shot also cause higher values of surface roughness [10]. Even at values of shot hardness which are lower than that of the workpiece distinct effects on topography could be found $[10,11]$. These effects are caused first by increasing strengths and therefore decreasing deformations if the workpiece hardness is increased, second by increasing kinetic energy of the shot if the shot size or the peening pressure are increased and third by decreasing tendency to plastic deformations of the shot if the shot hardness is increased. At high mass flow rates and peening pressures especially at ductile materials states the roughness may decrease due to effects of mutual impacts of shots in the nozzle and in the supplies which lead to decreasing kinetic energy [10]. While stress peening causes no significant changes in the effects on topography besides elliptic impact craters found by [12], warm peening slightly increases roughness with increasing peening temperature due to decreasing warm strength [13].

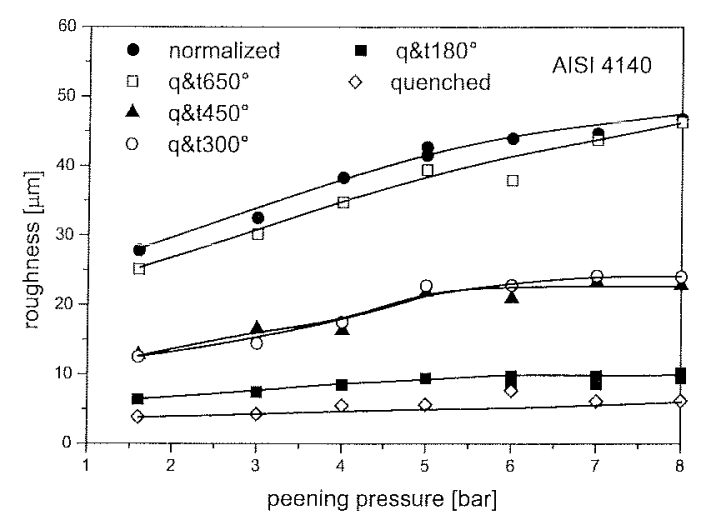

Figure 3: Influence of the workpiece state on roughness vs. peening pressure at AISI $4140(p=1.6$ bar, $\dot{m}=1.5 \mathrm{~kg} / \mathrm{min})[10]$

\section{$2.2 \quad$ Residual Stresses}

Fig. 4 shows typical residual stress distributions in differently heat treated and shot peened steel AISI 4140 [10]. With increasing hardness of the steel the surface residual stresses increase from the normalized state up to the state quenched and tempered at $450{ }^{\circ} \mathrm{C}$. Further increases of the workpiece hardness lead to surface residual stress decreases of up to $100 \mathrm{MPa}$. The depth of the zone bearing compressive residual stresses decreases with increasing workpiece hardness. Only the state quenched and tempered at $180^{\circ} \mathrm{C}$ shows a lower depth than the quenched state. A maximum value of compressive residual stresses below surface is characteristic for high strength 
material states and occurs at depths of up to $0.05 \mathrm{~mm}$ with values of up to $800 \mathrm{MPa}$. Fig. 5a shows the same results again as the dependence of characteristics of the residual stress distribution on the workpiece hardness. According to [14] the results found are due to the concurrent processes of plastic deformation during shot peening. At low workpiece hardness the plastic stretching of regions directly at the surface is dominating and the compressive residual stresses show their maximum directly at the surface. Only at extreme peening conditions, a maximum of the residual stresses below the surface may occur. At medium workpiece hardness plastic stretching of regions directly at the surface and Hertzian pressure are almost equivalent so that high residual stresses at the surface and a distinct maximum of residual stresses below the surface are combined. At high workpiece hardness the Hertzian pressure is dominating so that relatively low compressive residual stresses at the surface are combined with a very clear maximum of residual stresses below the surface. In accordance with [15] at the material state with the lowest tempering temperature higher compressive residual stresses than at the quenched state were found. This is typical for low shot hardnesses [16] and due to increases of strength in that tempering stage caused by the formation of energetically more favorable dislocation structures and carbon clusters which pin the dislocations [see e.g. 17].

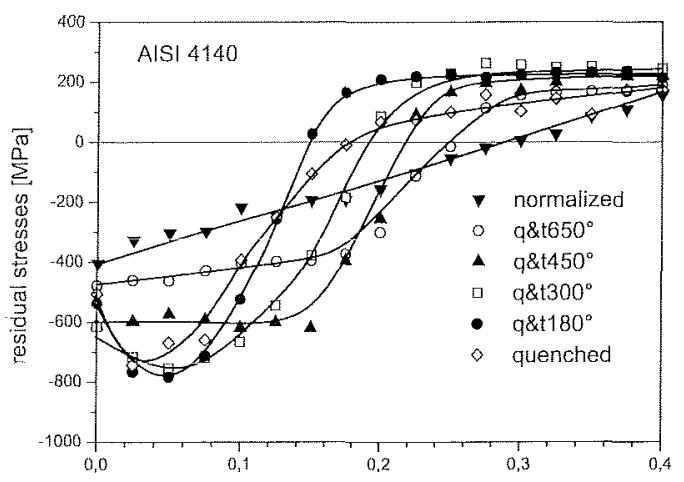

Figure 4: Influence of workpiece state on the residual stress distribution at AISI $4140 p=1.6$ bar, $\dot{m}=1.5 \mathrm{~kg} / \mathrm{min})[10]$

In Fig. $5 b$ the characteristics of the residual stress state of quenched AISI 4140 after shot peening are drawn for different shot sizes and hardnesses. The maximum and the surface values of compressive residual stresses are determined more by the hardness than by the size of the shot. In contrast to this, the depths of compressive residual stresses increase with increasing shot size and are almost not affected by changes of shot hardness. This can also be described by the model of [14] which indicates only slight changes of the positions of the maximum residual stresses induced by small changes of the size of the contact zone due to variation of the shot size at high workpiece hardness. Even the influence of shot hardness on the surface and maximum residual stress values is expected by the model in the same manner as found experimentally. According to Fig. $5 \mathrm{c}$ increasing peening pressures which determine the shot velocity in air blasting devices lead to no significant changes of the surface and maximum values of the residual stresses but increase the depth of compressive residual stresses and - at low pressures - the position of the maximum of the residual stresses. At high pressure the position of the maximum decrea- 


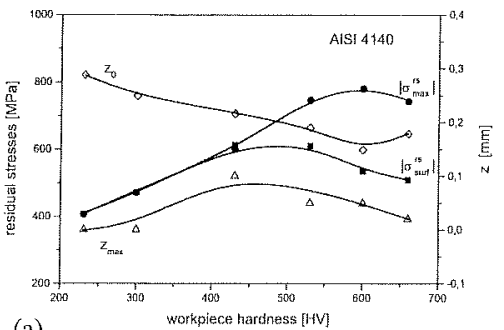

(a)

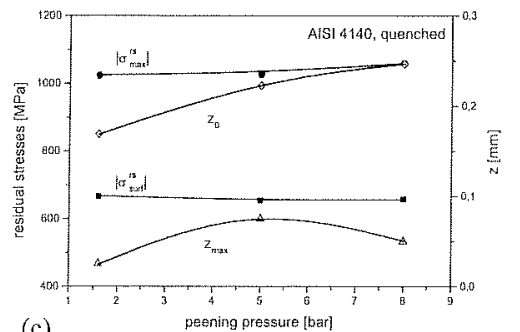

(c)

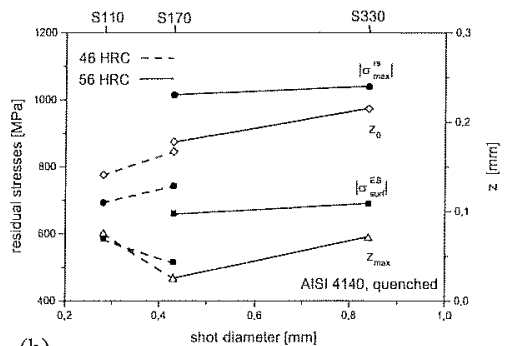

(b)

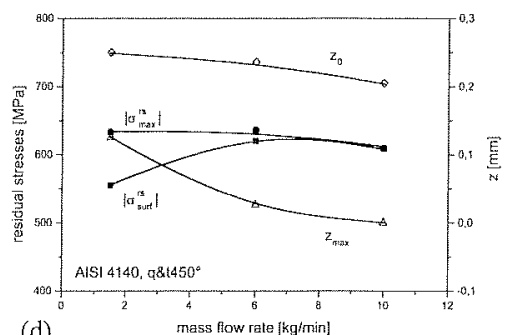

(d)

Figure 5: Influence of workpiece hardness (a), shot size and hardness (b), peening pressure (c) and mass flow rate (d) on the characteristics of the residual stress distribution at AISI 4140 [acc. 10]

ses again. This may be an effect of saturation, which could be found also for the depth of compressive residual stresses in the normalized state for peening pressures higher than 5 bar. Fig. $5 \mathrm{~d}$ shows for AISI 4140 quenched and tempered at $450{ }^{\circ} \mathrm{C}$ that with increasing media flow rate first the surface residual stresses increase to a value similar to the maximum value, so that the plateau of residual stresses typical for quenched and tempered steels forms. This plateau value seems to be not affected by the flow rate. According to mutual impacts of the particles - as described before at the effects on topography - the depth of compressive residual stresses decreases with growing flow rate. This effect could be proofed at a normalized state of AISI 4140, where coordinated changes of flow rate and peening time lead to a lower depth of the compressive residual stresses in the case of the higher flow rate at the same coverages [10]. According to [18], the impact angle of the shot leads to decreasing depths of compressive residual stresses if the component of the velocity normal to surface decreases. The residual stress state is no more rotational symmetric and shows decreasing compressive residual stresses in the direction with a tangential component of velocity. Perpendicular to this, the changes are not that pronounced because the plastic deformation in this this direction is not that affected by the angle of impact. These effects could be found also in finite-elemente-simulations of the shot peening process by [19] presented in these proceedings.

Fig. 6 shows measurements of macro residual stresses and phase specific micro residual stresses at the surface of iron-copper-titaniumcarbide sintered alloys in the shot peened state with different iron or copper contents [20]. While the macroscopic residual stresses are in the compressive region as expected and decrease with increasing copper content, the micro residual stresses are in the compressive region only for the two metallic phases and are equilibrated by tensile micro residual stresses in the TiC-phase. Therefore, at least at the copper content of 
about $10 \%$ the sum of the two residual stresses in the TiC-phase is positive and may promote decohesion of the interfaces and therefore crack initiation at tensile loadings of the material. This means that in bi- or multiphase materials the effect of shot peening on the residual stress state has to be observed precisely as it can be detrimental to the fatigue properties.

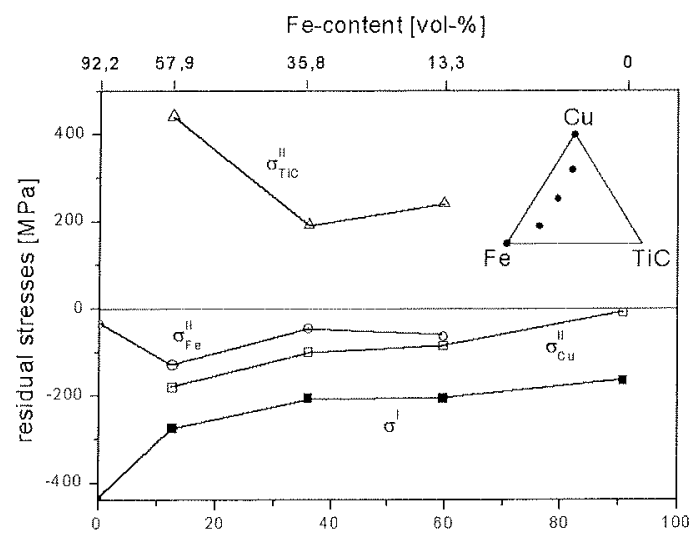

Figure 6: Macro and micro residual stresses in sintered Fe Cu-TiC sintered alloys [20]

At stress peening, the changes of the residual stress state with increasing prestress severely depend on the type of prestress, which may be uni- or bidirectional and homogeneous or inhomogeneous [21-28]. In general, the residual stress component in the direction of a positive prestress will increase, the residual stress component perpendicular to it will decrease and the depth of compressive residual stresses will increase due to stress peening. Fig. 7 shows this using the characteristics of the residual stress distributions for quenched and tempered AISI 4140 after stress peening with different torsional prestresses, which were tensile in the $45^{\circ}$-and compressi$v e$ in the $135^{\circ}$-direction [28]. Only at the highest prestress $\tau_{\text {pre }} / \tau_{\mathrm{e}}=0.8$ the residual stresses in $45^{\circ}$-direction decrease due to reverse plastifications during unloading. The effects of stress peening are the more pronounced the higher the strength of the workpiece is [29]. According to a model of [21-23] the residual stress changes are proportional to the prestress because the stress state directly after peening but before unloading is assumed to be independent of the prestress. During unloading from the prestress the stress state is shifted in the same way for the prestressed stress component and eventually in the opposite direction in the transverse direction. This model is valid up to prestresses of about half the yield stress as afterwards the residual stresses change only degressively due to the reverse plastifications during unloading mentioned before. The type of the prestress directly affects the changes of the two stress components on the prestress value. While at tensile or bending prestresses, which are uniaxial, the relation of the changes of the residual stresses perpendicular and parallel to the prestress is about one third, this is about two at torsional prestresses, which are biaxial with a positive and a negative stress component. At very high prestresses this may even lead to tensile residual stresses after torsional stress peening [30]. 


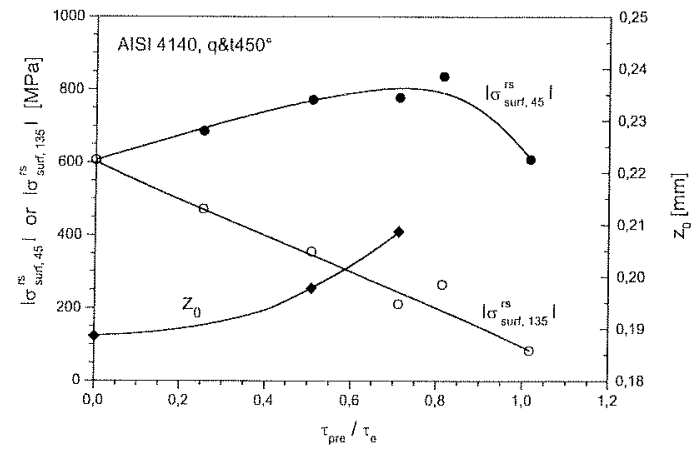

Figure 7: Influence of torsion prestress related to the yield stress on the characteristics of the residual stress distribution at quenched and tempered AISI 4140 [28]

Other important, but no more than recently upcoming modifications of shot peening are warm peening and stress peening at elevated temperatures. Fig. 8 shows the residual stress distributions in quenched and tempered AISI 4140 after these treatments in comparison to conventional peening [31]. While at warm peening the residual stresses in AISI 4140 initially increase only slightly with growing temperature and decrease above $330^{\circ} \mathrm{C}$ due to thermal residual stress relaxation, [32,33] found clear increases of the compressive residual stresses at the surface in a spring steel after warm peening. The residual stresses and the depth of compressive residual stresses after stress peening at elevated temperatures are increased again compared to stress peening and therefore can be explained by the superposition of the influences of prestress and peening temperature [31].

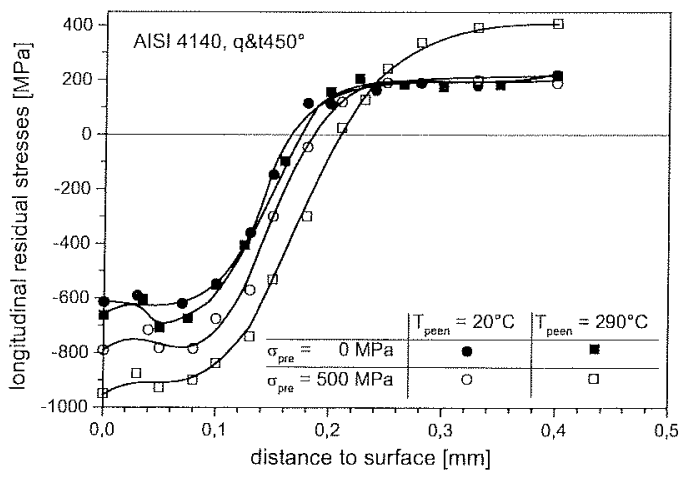

Figure 8: Residual stress distributions at quenched and tempered AISI 4140 after different modified shot peening treatments [27]

The last possible modifications of the shot peening process which should be mentioned in this paper are shot peening plus subsequent annealing treatments, which can be used to optimize the microstructure at the surface of steels and Al- as well as Ti-alloys. While at steels static strain aging effects are intended and reached at relatively low temperatures, which cause only 
slight relaxation of the residual stresses [34], at Al-and Ti-alloys the temperatures necessary to cause recrystallization or age hardening in the surface region are that high, that they lead to a severe relaxation of the residual stresses. This is shown exemplarily in Fig. 9 for the $\beta$-Ti-alloy Timetal $21 \mathrm{~s}[35]$.

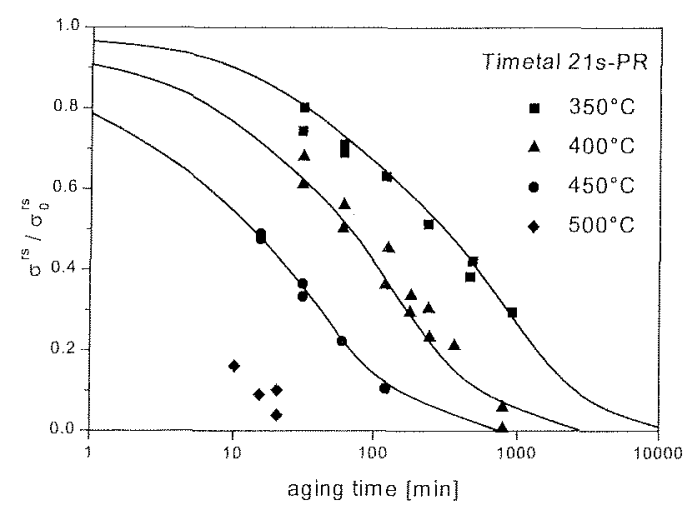

Figure 9: Influence of aging temperature and time on the relaxation of surface residual stresses at the shot peened $\beta$-Ti-alloy Timetal $21 \mathrm{~S}[35]$

\subsection{Workhardening State}

The changes of the workhardening state at the surface are also very important for the mechanical properties of shot peened material states. Fig. 10 shows the influence of the heat treatment state of shot peened steel AISI 4140 on the distributions of the half widths of x-ray interference lines which are a measure of the micro residual stresses. While they increase at the normalized state and the state tempered at $650{ }^{\circ} \mathrm{C}$ in the region affected by the shot peening treatment due to workhardening effects and show their highest values directly at the surface, they are not changed significantly at the state tempered at $450{ }^{\circ} \mathrm{C}$. In contrast to this, the states with the highest initial half width caused by high dislocation densities show decreasing half widths beneath the surface which increase slightly again directly at the surface. In contrast to this, the microhardness shown in Fig. 11 increases towards the surface not only at the soft materials states but also at the high strength states. As the half widths are a direct measure of the lattice distortions and therefore of the micro residual stresses induced by the dislocations [36] their increase at soft material states is due to increases of the dislocation density. In contrast to this, at hard material states decreases of the dislocation density occur as the initial dislocation density is very high and leads to dislocation rearrangements into energetically more favorable structures and to dislocation annihilations. Additionally, dissolved carbon atoms diffuse supported by the stored mechanical energy to octahedral sites where they cause lower lattice distortions due to the so called Snoek-effect [37] and decreasing half widths as found also by [36]. In contrast to this, microhardness measurements need plastic deformations and therefore are affected by the residual stress state in a way that compressive residual stresses lead to apparently increased hardness values [38]. Therefore, the microhardness is increased at hard materials states though the changes in the dislocation structure cause microstructural worksoftening. Changes of peening parameters like peening pressure, mass flow rate and velocity lead primarily to changes of the 
depth where the workhardening state of the bulk material is reached and not to severe changes in the surface value of half width or microhardness. As the measurement of this depth is very difficult, there are no statements known which are different from those already given when discussing the distributions of the residual stresses.

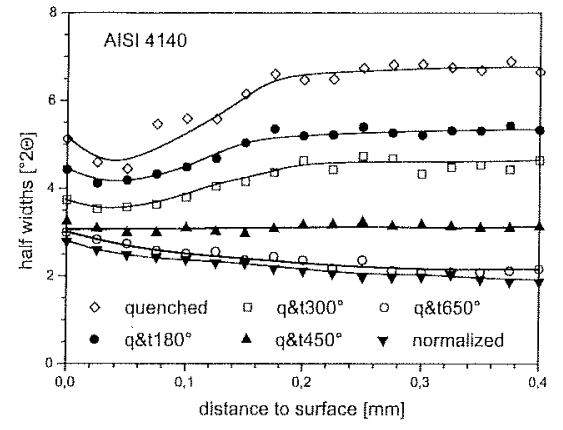

Fig. 10: Influence of the workpiece state on the half width distribution at AISI 4140 (S170 $46 \mathrm{HRC}, p=1.6$ bar $\dot{m}=1.5 \mathrm{~kg} / \mathrm{min})[10]$

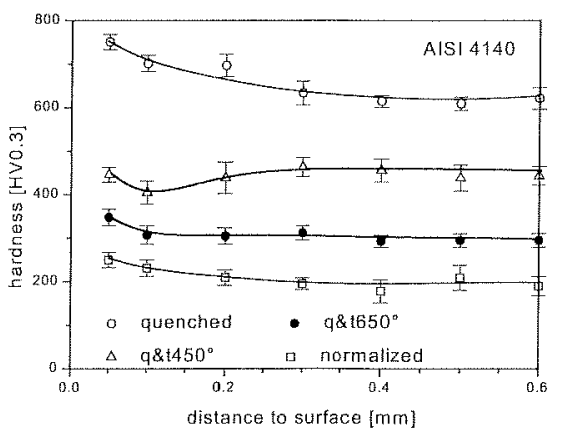

Fig. 11: Influence of the workpiece state on the microhardness distribution at AISI 4140 (S170 $46 \mathrm{HRC}, p=1.6 \mathrm{bar}, \dot{m}=1.5 \mathrm{~kg} / \mathrm{min})[10]$

While stress peening does not change the workhardening state significantly compared to conventional peening, after warm peening of steels increased half widths could be observed, which slightly decrease again at temperatures higher than $310^{\circ} \mathrm{C}$. According to [31] this is due to dynamic and static strain aging effects occurring during the peening process which lead to a lower mobility of the dislocations and therefore to multiplication of dislocations during further deformation. This causes increased values of the half widths. At very high temperatures thermal residual stress relaxation and dislocation rearrangements into energetically more favorable structures lead to decreasing half widths. After shot peening at different temperatures the microhardness of a high strength spring steel was investigated by [39-41]. As given in Fig. 12 it is increased at peening temperatures of $300{ }^{\circ} \mathrm{C}$ and above compared to conventionally peened samples. This effect is the higher, the higher the bulk hardness or the lower the tempering temperature is, resp., because the dissolved carbon content increases then. This is again a hint for the dynamic and static strain aging effects occuring during warm peening, which lead to diffuse dislocation structures pinned by clouds of carbon atoms or finest carbides $[42,43]$. Stress peening at elevated temperatures leads to surface half widths similar to those found in warm peened states but increased in larger regions below the surface.

Conventional peening and subsequent annealing of steels leads also to static strain aging effects and therefore dislocation structures pinned by carbon atom clouds and finest carbides [34]. Similar to warm peened states this leads to increasing microhardness values in the surface region [44]. At light metal alloys based on Titanium or Aluminum annealing treatments after shot peening can also be used to increase the hardness in the surface region. Fig. 13 shows that in the $\beta$-Ti-alloy Timetal 21S annealing treatments after shot peening induce hardness increases with increasing annealing time due to age hardening [35]. These are the more rapid the higher the an- 


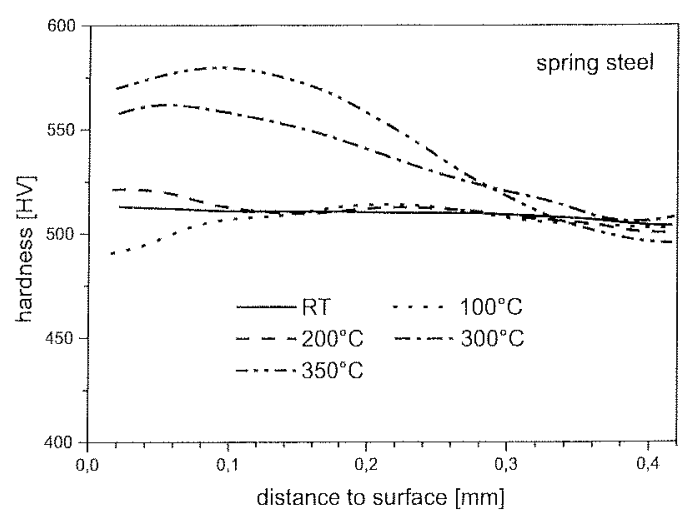

Figure 12: Influence of the peening temperature at the depth distribution of the microhardness in a spring steel

nealing temperature is and may be decreasing again at the highest annealing temperatures, if the annealing time is too large and overaging occurs.

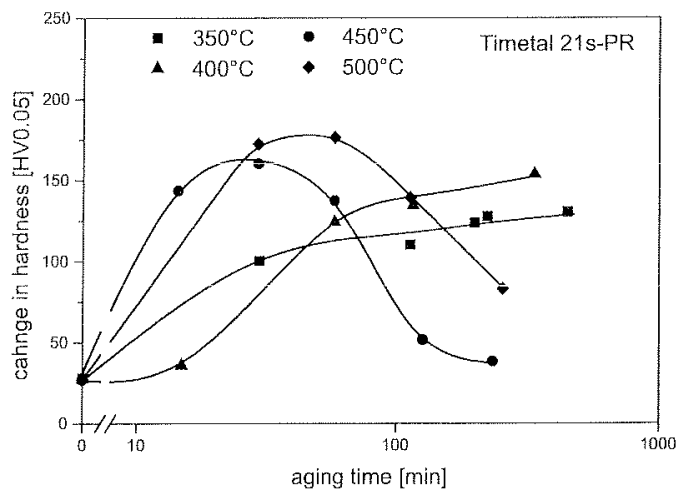

Figure 13: Influence of aging temperature and time on the increase of microhardness at the shot peened $\beta$-Ti-alloy Timetal 21S [35]

\subsection{Microstructure}

The microstructure is altered due to shot peening in thin surface layers, which are difficult to analyze microscopically. Therefore only few investigations exist, which in some cases use special preparation techniques like the so called cross sectional preparation to get informations about the microstructure in regions very close to the surface $[45,46]$. Using conventional transmission electron microscopic (TEM) preparation techniques, [47] studied the changes in the dislocation structure in normalized AISI 4140 due to shot peening given in Fig. 14. The dislocation structure, which is initially very low, is changed to a uniformly distributed structure with severely increased dislocation density. This is typical for deformations at high strain rate, which may reach up to $5 \cdot 10^{+3} 1 / \mathrm{s}$ during shot peening [47]. Similar results were obtained by [43,48], 
who determined depth profiles of the dislocation structure found in TEM-studies and found tangled dislocations with varying densities of up to $8 \cdot 10^{+11} 1 / \mathrm{cm}^{2}$. Another hint for high strain rate deformations was found by [49] who reports about twinning during TEM-studies of the Mg-alloy AZ31. [50] shows for normalized SAE1045 that the deformation is not restricted to the ferritic regions but affects also the pearlitic regions, where high densities of statistically distributed dislocations are observed between the cementite lamellae. For aluminum-alloys it could be shown by [51] that in AlMg5 the dislocations are uniformly distributed with increased dislocation density and only few dislocation tangles, whereas in AlMg1 the dislocations form sharp cells due to the stacking fault energy, which is three times higher than in AlMg5 and therefore allows much easier cross slip of screw dislocations.

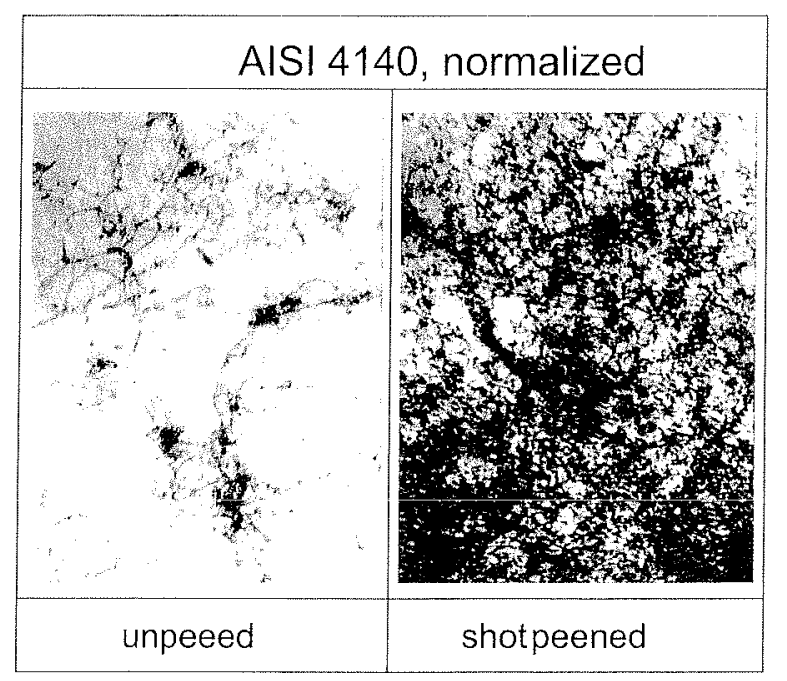

Figure 14: Dislocation structure close to the surface of unpeened and peened normalized AISI 4140 (S170, 54-58HRC, $p=1.0$ bar, 1 -fold coverage) [47]

In the surface region also other changes in the microstructure due to shot peening are observed. While [51] found a density of $7.72 \mathrm{~g} / \mathrm{cm}^{3}$ close to the surface in sintered iron with a bulk density of $7.37 \mathrm{~g} / \mathrm{cm}^{3}$, [52] describes decreases of the local porosity in unalloyed sintered steels due to ultrasonic peening, which are present in the larger depths, the higher the initial porosity is. Phase changes due to shot peening are well known especially in previously case hardened steels [53-57], hardened high carbon tool steels [58,59] and metastabile austenitic steels [5962], where austenite transforms to martensite. [63] observed transformations of retained austenite in the tool steel AISI D3 (German grade: X210Cr12) shown in Fig. 15 which bears the higher retained austenite after quenching, the higher the austenitizing temperature was. Due to shot peening the smaller transformations related to the initial value occur the higher the austenitizing temperature was. This is caused by increasing chemical stabilization of the austenite. Close to the surface the transformation to martensite is decreased significantly at the states with high retained austenite contents, so that the maximum of transformation is shifted to higher distances from surface with increasing initial retained austenite content. This may be explained by local temperature increases at the region close to the surface, which are increasing with decreasing di- 
stance to surface, as they are caused by local deformations which increase in that direction. This causes temperatures close to the surface higher than the critical temperature $M_{\mathrm{D}}$, above which no martensite formation is possible.

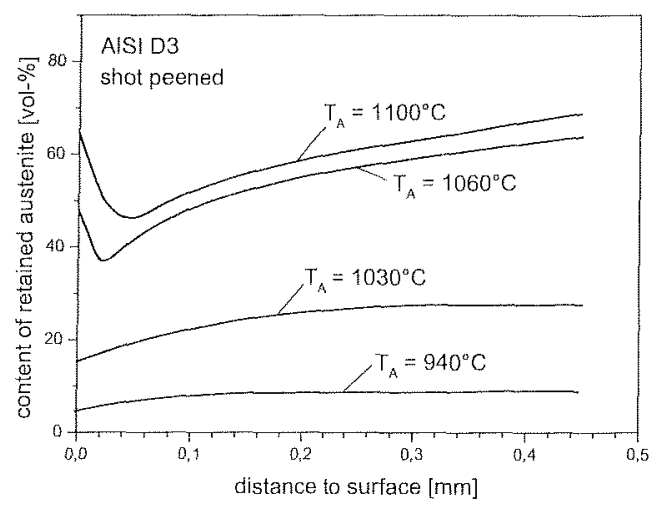

Figure 15: Influence of austenitizing temperature of the tool steel AISI D3 on the depth distribution of retained austenite after shot peening [63]

In TEM-studies at the austenitic steel AISI $304[43,48]$ observed strain induced martensite with contents of up to $40 \%$. Additionally they found a two phase nanocrystalline surface layer with a thickness of about $1-2 \mu \mathrm{m}$ consisting of austenite and martensite, which has grain sizes down to $20 \mathrm{~nm}$ directly at the surface. This layer is a hint for static recrystallization during shot peening. Similar effects were found by [64] after ultrasonic peening of AIST 316L, by [65] at $\alpha-$ iron and by [66-69] at Nickel-base alloys. The severe plastic deformations during shot peening lead to changes in the grain orientation so that characteristic peening textures occur in states initially free of textures or preexisting textures may be changed by shot peening [see e.g. 70].

Annealing treatments after shot peening of aluminum and titanium alloys, used as modifications of the shot peening process, may lead to changes of the microstructure, which can be separated into four different mechanisms. In $\alpha$-Ti-alloys like Ti-8Al, e.g., local recrystallization causes fine grained zones close to the surface because of the high nucleation rate for new grains in the deformed surface regions [71]. In $(\alpha+\beta)$-Ti-alloys like Ti-6Al-4V, e.g., local recrystallization may change the fine grained lamellar structure of the bulk material to an equiaxed fine grained surface region [72]. In $\beta$-Ti-alloys like BetaC or Timetal $21 \mathrm{~S}$ selective surface aging can be obtained by local precipitation of semi- or incoherent $\alpha$-particles. This is possible due to the high dislocation density and therefore increased density of nuclei which decrease the precipitation times in the TTT-diagram and allow aging treatments which do not affect the bulk material but cause fine precipitations in the surface region. As they are finer than obtained by an aging treatment of the full material, the microhardness in the surface regions is increased to much higher values [35]. At age hardening Al-alloys like 2017 or 2024, e.g., preferred surface aging treatments can be performed, because shot peening leads also to increased dislocation densities and therefore increased densities of the nuclei for precipitation. In contrast to the $\alpha$-Ti-alloys, in these materials the precipitation in the bulk material cannot be suppressed, so that in the surface 
region only a higher number of smaller precipitates occurs, leading to increased hardness values in those areas [73].

\section{Concluding Remarks}

It is shown that shot peening causes multiple changes in the state of the material close to the surface of components. These changes which cannot be adjusted independently but can be separated into the categories topography, residual stress state, workhardening state and microstructure. It could be shown that there are numerous process parameters, whose influence on the state of the material close to the surface can only be understood because there are sufficiently systematic investigations in that area.

The interactions of the surface state with the mechanical properties especially at cyclic loading are of particular interest. In this context, the stability of the changes in the surface state induced by shot peening, especially the residual stress state, is very important [31]. Though both aspects are not directly subject of this paper they lead to modifications of the shot peening treatments which get more and more important in technical practice and therefore are included in the paper. One of these is stress peening, which yields higher and deeper residual stress states and consequently leads to higher fatigue limits if the material strength is high enough to impede the relaxation of these increased residual stresses [21-28]. Another one is warm peening, which leads to dynamic and static strain aging effects, therefore to increased microhardness values, stabilized residual stresses and severely increased fatigue properties at steels $[31,42,74]$. At other materials which are able to strain aging similar effects should be expected. Combinations of stress and warm peening may use the advantages of both types of modifications but lead to less pronounced effects than would be necessary to vindicate the efforts for their technical application. Last but not least annealing treatments subsequent to conventional shot peening may be of benefit at steels and some light weight alloys. While they may cause static stain aging effects in steels and lead to slightly weakened increases of the fatigue behaviour compared to warm peening, they may be utilized for several effects in light weight alloys. This is first the formation of fine grained surface regions by recrystallization, which leads to optimized fatigue properties, because fine grained surface states may impede crack initiation and the coarse grained bulk material shows relatively low crack propagation rates [71]. Second, changes of grain morphology due to recrystallization can be obtained. This may lead to optimized properties at combined creep-fatigue loadings because creep resistant lamellar bulk materials can be combined with fatigue resistant fine and equiaxially grained surface, e.g. [72]. Third, selective or preferred surface aging can be performed causing increased hardness values at the surface region and fatigue limits enhanced compared to the states aged before shot peening $[35,73]$. All of these modified shot peening treatments are a fine example for the feedbacks of the systematic studies on the correlations between process parameters and surface characteristics mentioned before. 


\section{References}

[1] O. Föppl, Stahl und Eisen, 49 (1929), 775.

[2] O. Föppl, G. v. Heydekampf, Dauerfestigkeit und Konstruktion, Metallwirtschaft Wissenschaft und Technik 45 (1929), 1087-1094.

[3] A. Thum, H. Wiegand, Die Dauerhaltbarkeit von Schraubenverbindungen und Mittel zu ihrer Steigerung, VDI Z 39 (1933), 1061-1063.

[4] H. Oschatz, Gesetzmäßigkeiten des Dauerbruches und Wege zur Steigerung der Dauerhaltbarkeit, Mitteilungen der Materialprüfungsanstalt an der Technischen Hochschule Darmstadt, 1933.

[5] E. Houdremont, R. Mailänder, Archiv Eisenhüttenwesen 49 (1929), 833.

[6] E. Siebel, M. Gaier, Untersuchungen über den Einfluß der Oberflächenbeschaffenheit auf die Dauerschwingfestigkeit metallischer Bauteile, VDI Z 30 (1956), 1715-1723.

[7] E. Macherauch, H. Wohlfahrt, Eigenspannungen und Ermüdung, In: D. Munz (ed.) Ermüdungsverhalten metallischer Werkstoffe, DGM-Informationsgesellschaft, Oberursel, 1985, 237-283.

[8] P. Starker, H. Wohlfahrt, E. Macherauch, Surface crack initiation during fatigue as a result of residual stresses, Fatigue and Fracture of Engineering Materials \& Structures 1 (1979), 319-327.

[9] D. Löhe, K.-H. Lang, O. Vöhringer, Residual stresses and fatigue behavior, In: G. Totten, M. Howes, T. Inoue (eds.), Handbook of residual stress and deformation of steel, ASM International, 2002, 27-53.

[10] H. Holzapfel, A. Wick, V. Schulze, O. Vöhringer, Einfluß der Kugelstrahlparameter auf die Randschichteigenschaften von 42 CrMo 4, Härterei-Techn. Mitt.53 (1998), 155-163.

[11] P. Martin, Dr.-Ing. Thesis, Universität Hamburg, 1980.

[12] R. Kopp, In: H. O. Fuchs (ed.) Proc. ICSP 2, Paramus, N.J., 1984.

[13] U. Martin, B. Scholtes, K. Kremmer, H. Oettel, Characterization of the defect depth profile of shot peened steels by transmission electron microscopy, In: J. Champaigne (ed.) Proc. ICSP 6, San Francisco, 1996, 142-153. 1996.

[14] H. Wohlfahrt, Ein Modell zur Vorhersage kugelstrahlbedingter Eigenspannungszustände, In: E. Macherauch, V. Hauk (eds.) Eigenspannungen: Enstehung-Messung-Bewertung, DGM-Informationsgesellschaft, Oberursel, 1983, 301-319.

[15] H. Wohlfahrt, Residual stress and stress relaxation, In: E. Kula, V. Weiss (eds.) Proc. Sagamore Army Mat. Res. Conference, 1982, 71.

[16] B. Scholtes, Eigenspannungen in mechanisch randschichtverformten Werkstoffzuständen, Ursachen-Ermittlung-Bewertung. DGM-Informationsgesellschaft, Oberursel, 1990.

[17] B. Hoffmann, O. Vöhringer, E. Macherauch, Effect of compressive plastic deformation on mean lattice strains, dislocation densities and flow stresses of martensitically hardened steels, Mat.Sci. \& Eng. A319-321(2001), 299-303.

[18] A. Ebenau, O. Vöhringer, E. Macherauch, In: H. Wohlfahıt, R. Kopp, O. Vöhringer (eds.) Prof. ICSP 3, DGM-Informationsgesellschaft, Oberursel, 1987, 253.,

[19] J. Schwarzer, V. Schulze, O. Vöhringer, Finite element simulation of shot peening - A Method to evaluate the influence of peening parameters on surface characteristics, In: L. Wagner (ed.) Proc. ICSP 8, Wiley-VCH, Weinheim, 2002. 
[20] V. Hauk, B. Krüger, Residual stresses in Cu-FE-TiC sintered materials after grinding and after shot peening, Z. Metallkde 93(2002), 76-80

[21] R. Zeller, Kugelstrahlen unter Zugvorspannung, Materialprüfung 35 (1993), 218-221.

[22] L. Bonus, Auswirkungen des Spannungsstrahlens auf die Eigenschaften von hoch vergüteten Bremsspeicher- und Torsionsfedern, Dr.-Ing. Thesis, RWTH Aachen, 1994.

[23] J. F. Flavenot, A. Niku-Lari, La Mesure des Contraintes Résiduelles: Methode de la Flêche - Methode de la Source des Contraintes, Les mémoires techniques du CETIM, 1977, 31.

[24] J. C. Xu, D. Zhang, B. Shen, In: A. Niku-Lari (ed.) Proc. ICSP 1, Oxford, 1982, 367.

[25] E. Müller, Die Ausbildung von Eigenspannungen an Torsionsproben beim Spannungsstrahlen, Mat.wiss. u. Werkstofftechnik 27 (1996), 354-358.

[26] F. Engelmohr, B. Fiedler, Erhöhung der Dauerfestigkeit geschmiedeter Pleuel durch Kugelstrahlen unter Vorspannung, Mat.wiss. u. Werkstofftechnik 22 (1991), 211-216.

[27] A. Wick, V. Schulze, O. Vöhringer, Effects of stress- and/or warm peening of AISI 4140 on fatigue life, Steel Research 71(2000), 316-321.

[28] V. Schulze, Warm- und Spannungsstrahlen - Wege zur Erzeugung stabilisierter und erhöhter Druckeigenspannungen, Proc. DVM-Tag "Federn im Fahrzeugbau", DVM, Berlin, $2002,45-54$.

[29] A. Wick, Randschichtzustand und Schwingfestigkeit von $42 \mathrm{CrMo} 4$ nach Kugelstrahlen unter Vorspannung und bei erhöhter Temperatur, Dr.-Ing. Thesis, Universität Karlsruhe (TH), 1999.

[30] J. Krobb, H. Weiß, Stress peening of ultra high strength steels, In: T.S. Sudarshan, M. Jeandin, K. A. Khor (eds.) Proc. SMT XI, London, 1997, 423-429.

[31] A. Wick, V. Schulze, O. Vöhringer, Effects of warm peening on fatigue life and relaxation behaviour of residual stresses of AISI 4140, Mat. Sci. \& Eng. A 293 (2000), 191-197.

[32] M. Schilling-Praetzel, F. Hegemann, P. Gome, G. Gottstein, Influence of Temperature of Shot Peening on Fatigue Life, In: D. Kirk (ed.) Proc. ICSP 5, 1993, 227-238.

[33] M. Schilling-Praetzel, Einfluß der Werkstücktemperatur beim Kugelstrahlen auf die Schwingfestigkeit von Drehstabfedern, Dr.-Ing. Thesis, RWTH Aachen, 1995.

[34] R. Menig, V. Schulze, O. Vöhringer, Effects of static strain aging on residual stress stability and alternating bending strength of shot peened AISI 4140, Z. Metallkde 93 (2002), $635-640$

[35] M.-C. Berger, J. K. Gregory, Selective hardening and residual stress relaxation in shot peened Timetal 21S, In: C.A. Brebbia, J.M. Kenny, (eds.) Proc. Surface Treatment IV, 1999.

[36] F. Burgahn, O. Vöhringer, E. Macherauch, Mikroeigenspannungszustände kugelgestrahlter Randschichten von 42 CrMo 4, Z. Metallkde 84 (1984), 224-229.

[37] J. L. Snoek, Effect of small quantities of carbon and nitrogen on the elastic and plastic properties of iron, Physica 8 (1941), 711-733.

[38] H. H. Racké, T. Fett, Die Bestimmung biaxialer Eigenspannungen in Kunststoff-Oberflächen durch Knoop-Härtemessung, Mat.prüfg. 13(1971), 37-42.

[39] A. Tange, H. Koyama, H. Tsuji, Study on warm shot peening for suspension coil spring, SAE Technical Paper Series 1999 01-0415, 1999, 1-5.

[40] A. Tange, H. Koyama, H. Tsuji, The effect of warm shot peening on the fatigue strength of springs, Springs, 2000, 58-63. 
[41] Y. Harada, K. Mori, Y. Fukuoka, S. Maki, Effect of processing temperature on warm shot peening of spring steel, J. Jap. Soc. Technology and Plasticity 40 (2000), 260-264.

[42] R. Menig, V. Schulze, O. Vöhringer, Optimized warm peening of the quenched and tempered steel AISI 4140, Mat. Sci. \& Eng. A 335 (2002), 198-206.

[43] I. Altenberger, Mikrostrukturelle Untersuchungen mechanisch randverfestigter Bereiche schwingend beanspruchter metallischer Werkstoffe, Dr.-Ing. Thesis, Universität Gesamthochschule Kassel, 2000.

[44] R. Menig, Randschichtzustand, Eigenspannungsstabilität und Schwingfestigkeit von unterschiedlich wärmebehandeltem $42 \mathrm{CrMo} 4$ nach modifizierten Kugelstrahlbehandlungen, Dr.-Ing. Thesis, Universität Karlsruhe (TH), 2002.

[45] U. Martin, I. Altenberger, K. Kremmer, B. Scholtes, H. Oettel, Characterization of the microsturcture-depth profile of shot peened steels, Praktische Metallographie 35 (1998), $327-334$.

[46] F. Y. Hu H.-J. Klaar, Praktische Metallographie 32 (1995), 603.

[47] B. Scholtes, E. Macherauch, Randschichtzustände von normalisiertem und vergütetem 42 CrMo 4 nach konsekutiven Kugelstrahlen- und Festwalzbehandlungen, Mat.wiss. u. Werkstofftechnik 23 (1992), 388-394.

[48] U. Martin, I. Altenberger, B. Scholtes, K. Kremmer, H. Oettel, Cyclic deformation and near surface microstructures of normalized shot peened steel SAE 1045, Mat. Sci. \& Eng. A 246 (1998), 69-80.

[49] I. Altenberger, U. Martin, B. Scholtes, H. Oettel, Near surface microstructures in mechanically surface treated materials and their consequences on cyclic deformation behaviour, In: A. Nakonieczny (ed.) Proc. ICSP 7, Warschau, 1999, 79-87.

[50] B. Scholtes, unpublished results, Universität Gesamthochschule Kassel., 1993.

[51] B. Scholtes, O. Vöhringer, Ursachen, Ermittlung und Bewertung von Randschichtveränderungen durch Kugelstrahlen, Mat.wiss. und Werkstofftechnik 24 (1993), 421-432.

[52] H. Chardin, M. Jeandin, Ultrasonic shot-peening of a low-carbon porous sintered steel, In: J. Lu (ed.) Proc. Mat-Tec 96, Paris, 1996, 195-204.

[53] S. Pakrasi, J. Betzold, In: A. Niku-Lari (ed.) Proc. ICSP 1, 1982, 193.

[54] D. Kirk, Proc. A. Niku-Lari (ed.) ICSP 1, 1982, 271.

[55] M. Kikuchi, H. Ueda, K. Hanai, T. Naito, In: H. O. Fuchs (ed.) Proc. ICSP 2. Paramus, NJ, USA, 1984, 208.

[56] S. Hisamatsu, T. Kanazawa, In: H. Wohlfahrt, R. Kopp, O. Vöhringer (eds.) Prof. ICSP 3 , DGM-Informationsgesellschaft, Oberursel, 1987, 517.

[57] Th. Hirsch, H. Wohlfahrt, E .Macherauch, Fatigue Strength of Case Hardened and Shot Peened Gears, In: H. Wohlfahrt, R. Kopp, O. Vöhringer (eds.) Prof. ICSP 3, DGM-Informationsgesellschaft, Oberursel, 1987, 547-560.

[58] O. Vöhringer: Changes in the state of the material by shot peening, In: H. Wohlfahrt, R. Kopp, O. Vöhringer (eds.) Prof. ICSP 3, DGM-Informationsgesellschaft, Oberursel, 1987, 185-204.

[59] D. Wehrle, A. Ebenau, unpublished results, Universität Karlsruhe (TH), 1987.

[60] H. Wohlfahrt, Festigkeitsstrahlen, In: D. Aurich (ed.) Bauteile 86 - Die Bauteiloberfläche, 1986, 23-35. 
[61] R. Herzog, W. Zinn, B. Scholtes, H. Wohlfahrt, The significance of almen intensity for the generation of shot peening residual stresses, In: J. Champaigne (ed.) Proc. ICSP 6, San Francisco, 1996, 270-281.

[62] D. Kirk, N. J. Payne, Transformation induced in austenitic stainless steels by shot peening, In: A. Nakonieczny (ed.) Proc. ICSP 7, Warschau, 1999, 15-22.

[63] A. Ebenau, Verhalten von kugelgestrahltem 42 CrMo 4 im normalisierten und vergüteten Zustand unter einachsig homogener und inhomogener Beanspruchung, Dr.-Ing. Thesis, Universität Karlrsruhe (TH), 1989.

[64] G. Liu, J. Lu, K. Lu, Surface nanocrystallization of $316 \mathrm{~L}$ stainless steel induced by ultrasonic shot peening, Mat. Sci. \& Eng. A 286 (2000), 91-95.

[65] K. Lu, J. Lu, J. Mater, Mat. Sci \& Techn. 15 (1999), 193.

[66] M. K. Tufft, Instrumented single particle impact tests using production shot: the role of velocity, incidence angle and shot size on impact response, induced plastic strain and life behavior, In: J. Champaigne (ed.) Proc. ICSP 6, San Francisco, 1996.

[67] M. K. Tufft, Development of a fracture mechanics / Treshold behavior model to assess the effects of competing mechanisms induced by shot peening on cyclic life of a nickel-base superalloy, René 88DT, Dr.-Ing. Thesis, University of Dayton, Ohio, 1997

[68] R. Wang, X. Zhang, D. Song, Y. Yin, In: A. Niku-Lari (ed.) Proc. ICSP 1, 1982, 395.

[69] P. Li, G. Spur, Berichte aus dem Produktionstechnischen Zentrum, Berlin, 2002.

[70] G. Maurer, H. Neff, B. Scholtes, E. Macherauch, Texture and lattice deformation pole figures of machined surfaces, Textures and Microstructures 8 (1988), 639-678.

[71] L. Wagner, J. K. Gregory, Thermomechanical surface treatment of titanium alloy, Proc. $2^{\text {nd }}$ ASM Heăt Treatment and Surface Engineering Conference, Dortmund, 1993, 1-24.

[72] H. Gray, L. Wagner, G. Lütjering, Effect of modified surface layer microsturctures through shot peening and subsequent heat treatment on the elevated temperature fatigue behavior of Titanium-Alloys, In: H. Wohlfahrt, R. Kopp, O. Vöhringer (eds.), Proc. ICSP 3, 1987, 467-475.

[73] J. K. Gregory, C. Müller, L. Wagner, Bevorzugte Randschichtaushärtung: Neue Verfahren zur Verbesserung des Dauerschwingverhaltens mechanisch belasteter Bauteile, Metall 47 (1993), 915-919.

[74] A. Tange, K. Ando, Study on the shot peening processes of coil spring, In: Proc. ICRS 6, Oxford, IOM Communications, 2000, 897-904. 